\title{
Health risks of the clean-shave chiskop haircut
}

\author{
N P Khumalo, ${ }^{1}$ FCDerm, PhD; N Gantsho, ${ }^{1}$ BSc, MB ChB; F Gumedze, ${ }^{2} \mathrm{PhD} ;$ T Mthebe ${ }^{3}$ MB ChB \\ ${ }^{1}$ Division of Dermatology, Faculty of Health Sciences, University of Cape Town, South Africa \\ ${ }^{2}$ Department of Statistical Sciences, University of Cape Town, South Africa \\ ${ }^{3}$ Langa Community Health Clinic, Cape Town Central Health District, Western Cape, South Africa
}

Corresponding author: N P Khumalo (n.khumalo@uct.ac.za)

\begin{abstract}
The clean-shave haircut known locally as the chiskop is rare among females but popular with black South African men, who are also predisposed to folliculitis keloidalis nuchae (FKN) (keloids on the back of the head). During a previous study, participants described an unexpected symptom of haircut-associated bleeding. As this is not a widely recognised entity, we conducted the present study at an HIV clinic servicing the same population, with the objective of comparing the prevalences of haircut-associated bleeding and FKN in 390 HIVpositive subjects with published data for Langa (Western Cape, South Africa). The results for HIV-positive participants were similar to the population data, but in both groups the prevalence of haircut-associated bleeding ( $24.5 \%$ v. $32 \%$; $p=0.17)$ was much higher than that of FKN (10.2\% v. 10.5\%), suggesting that the hairstyle increases the risk of bleeding even in people with healthy scalps without folliculitis. This study does not (and was not intended to) prove a higher HIV prevalence in chiskop wearers or in FKN sufferers, but it confirms a history of haircut-associated bleeding in at least a quarter of our male study participants. The risk of transmission of blood-borne infection via haircuts is likely to be low, but requires formal quantification. Public education on adequate sterilisation of barber equipment between haircuts and promotion of individual hair-clipper ownership for chiskop clients should not be delayed. Depilatory creams formulated for African hair offer a non-mechanical means of achieving clean-shave hairstyles.
\end{abstract}

S Afr Med J 2013;103(7):489-490. DOI:10.7196/SAMJ.6675

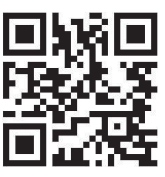

Close-shave haircuts are rare among females but worn by over $70 \%$ of black males in the Langa population (Western Cape, South Africa). ${ }^{[1]}$ The most popular of these is the 'clean-shave' or 'chiskop' style, which is achieved when the metal of the electric clipper is pressed directly onto the scalp to produce a shiny look similar to that achieved with razor blades. Folliculitis keloidalis nuchae (FKN), also incorrectly called acne keloidalis, is shaving-bump-like keloids on the back of the head (Fig. 1); the condition predominantly affects black males $\left(5.4 \%\right.$ of high-school boys v. $0 \%$ of girls; ${ }^{[2]}$ $10.5 \%$ of men v. $0.3 \%$ of women $\left.{ }^{[1]}\right)$. We had an unexpected finding during a population study; $32 \%$ of male participants described having experienced haircut-associated bleeding, ${ }^{[3]}$ which may be significant in our country with its high burden of HIV infection. ${ }^{[4]}$ Only a few small studies have investigated knowledge of HIV and sterilisation practices among barbers. ${ }^{[5,6]}$ Haircut-associated bleeding is not a widely recognised entity, and has only been reported in one population study. ${ }^{[1]}$

\section{Methods}

We conducted a cross-sectional study of attendees at the Langa HIV Clinic, which serves the same community (including schools, churches and community groups) that featured in our original studies. ${ }^{[1,2]}$ We obtained approval from the Ethics Committee of the Faculty of Health Sciences, University of Cape Town, permission from the Cape Town Central Health District, Western Cape, and informed consent from participants. Our aim was to compare the prevalences of haircut-associated bleeding and FKN with existing Langa population data. The clinical diagnosis of FKN was based on the presence of keloidal papules or plaques on the nuchal scalp. A brief questionnaire included questions on the history of haircutassociated bleeding and scalp symptoms, as well as past/present sexual partners' hair care practices and whether they had scalp keloidal lesions. STATA software version 10 was used for statistical analysis and the chi-square test or Fisher's exact test and a $95 \%$ confidence interval for comparison.

\section{Results}

During the 1-year study period, 390 participants were recruited: 158 males (mean age 38.6 years, range 20 - 71 years) and 232 females (mean age 34.5 years, range $18-78$ years). The prevalence of FKN in HIVpositive participants was $10.2 \%(15 / 147)$ for males versus $0.9 \%(2 / 220)$ for females. In addition, $10.05 \%$ of females (22/219) as opposed to

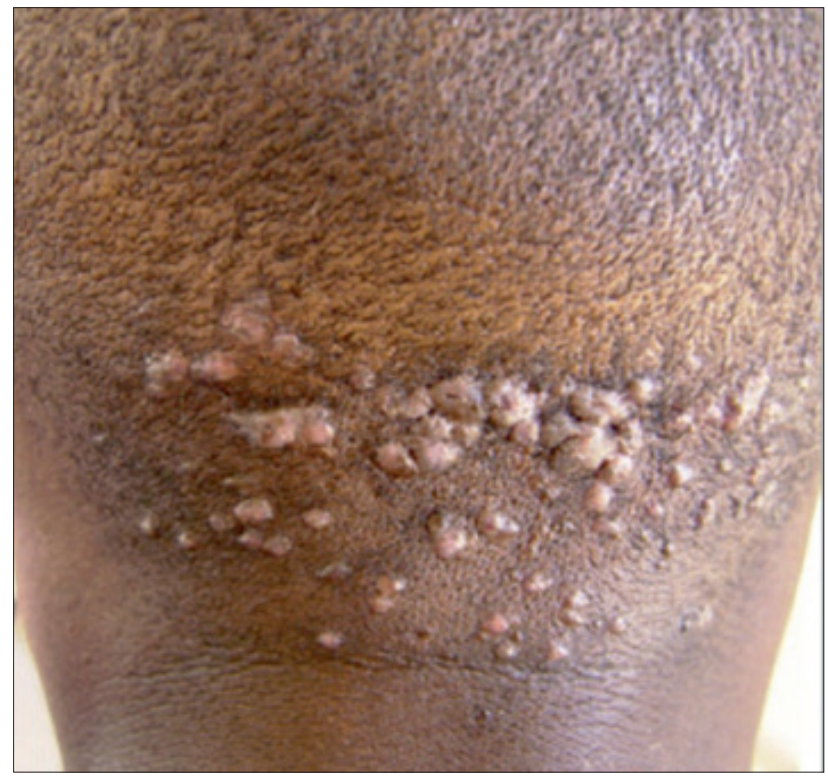

Fig. 1. A patient with keloidal papules and plaques on the nuchal scalp (folliculitis keloidalis nuchae) is wearing a clean-shave chiskop haircut. 
$1.4 \%$ of males (2/147) reported ever having had had sexual intercourse with a partner who had FKN ('scalp pimples as in the picture'). There was an association between haircut symptoms and FKN $(p<0.0001)$. In addition, $24.7 \%$ of males $(36 / 145)$ had 'ever bled' from a haircut.

The prevalence of FKN in HIV-positive males was similar to the Langa population data $(10.2 \%$ v. $10.5 \%)$, while that in females was higher, but not significantly so $(0.9 \%$ v. $0.3 \% ; p=0.30)$. In male partners of female participants, the prevalence of FKN was similar to the male population data (10.05\% v. $10.5 \%)$, and in female partners of male participants it was higher, but again not significantly higher, than the female population data $(1.4 \%$ v. $0.3 \% ; p=0.12)$. Although the prevalence of haircut-associated bleeding was lower than in the previous study ${ }^{[1]}$ (but not significantly lower, $24.6 \%$ v. $32 \%$; $p=0.17$ ), it was noteworthy that bleeding was common in both studies. Additionally, more participants had a history of bleeding from a haircut than were diagnosed with FKN, suggesting that this haircut increases the risk of bleeding even in people with healthy scalps.

\section{Discussion}

Unlike other inflammatory skin disorders, FKN does not appear to be more prevalent in people with HIV infection. The scalp lesions of FKN would be expected to increase the risk of injury during chiskop haircuts. What we found more worrying was that the popular chiskop haircut is a risk factor for injury independent of the presence of FKN. To maintain the chiskop style, the scalp has to be shaved at 1 - 2-weekly intervals; this is often done at facilities (such as old shipping containers and informal structures) with a high client turnover, no running water, and little (e.g. methylated spirits) or no disinfection/sterilisation of razors between clients. ${ }^{[5,6]}$ Accidental cuts (involving 3.3\% of clients ) have been reported ${ }^{[6]}$ Hepatitis B virus has been detected on $6.6 \%$ of barbering blades, ${ }^{[7]}$ but we found no data investigating associations with HIV.

Shaving of part of or the whole scalp was routinely performed for religious expression in medieval times. Tonsure is still widely practised as a sacrifice in Hindu temples, but at most several times during a believer's life, ${ }^{[8]}$ which is much less frequent than the 1 - 2-weekly shaves required to maintain a chiskop. There are no published data on whether inadequate sterilisation of blades contributes to the high HIV burden in India. The prevalence of HIV in Nigeria, the most populous African country, is significantly lower than that in South Africa (3.6\% v. 17.8\%). The only published data on disease transmission by barbering blades come from Nigeria, ${ }^{[5,6]}$ which is also the country in which the concept of individuals bringing their own hair clippers to the barber shop originated; this may be coincidental, or represent awareness of risk of HIV transmission that contributes to that country's lower HIV burden.

The risk of disease transmission per haircut with a contaminated clipper is likely to be low, but overall the risk may not be insignificant taking into account the popularity of the chiskop and the prevalence of HIV in our population. Clean-shave haircuts are risk factors for injury independent of FKN. Contrary to popular belief, the HI virus remains viable for several days at room temperature in dried blood on surfaces ${ }^{[9]}$ and may be resistant to commonly used disinfectants. ${ }^{[10]}$ Since a cure and/or an effective HIV vaccine remain elusive, potential methods of disease transmission should be identified for disease prevention. This study does not (and was not intended to) prove a higher HIV prevalence in chiskop wearers or in FKN sufferers, but confirms a history of haircut-associated bleeding in at least a quarter of our male subjects. The potential contribution to HIV transmission requires quantification, but public education regarding adequate sterilisation of barbering equipment between clients and promotion of individual hair-clipper ownership for chiskop wearers should not be delayed. Chemical depilatories may offer a safe alternative to mechanical clean-shave haircuts.

Acknowledgements. We are grateful to Sr Petlho, Sr Kwini, Mr Joboda and the rest of the Langa Clinic staff, without whom the study would not have been possible.

\section{References}

1. Khumalo NP, Jessop S, Gumedze F, et al. Hairdressing and the prevalence of scalp disease in African adults. Br J Dermatol 2007;157(5):981-988. [http://dx.doi.org/10.1111/j.1365-2133.2007.08146.x]

2. Khumalo NP, Jessop S, Gumedze F, et al. Hairdressing is associated with scalp disease in African schoolchildren. Br J Dermatol 2007;157(1):106-110. [http://dx.doi.org/10.1111/j.13652133.2007.07987.x

3. Khumalo NP, Gumedze F, Lehloenya R. Folliculitis keloidalis nuchae is associated with the risk for bleeding from haircuts. Int J Dermatol 2011;50(10):1212-1216. [http://dx.doi.org/10.1111/j.13654632.2010.04655.x

4. Rehle TM, Hallett TB, Shisana O, et al. A decline in new HIV infections in South Africa: Estimating HIV incidence from three national HIV surveys in 2002, 2005 and 2008. PLoS ONE 2010;5:e1 1094. [http://dx.doi.org/10.1371\%2Fjournal.pone.0011094]

5. Salami KK, Titiloye MA, Brieger WR, Otusanya SA. Observations of barbers' activities in Oyo State, Nigeria: Implications for HIV/AIDS transmission. Int Q Community Health Educ 2005;24(4):319-330. 6. Arulogun OS, Adesoro MO. Potential risk of HIV transmission in barbering practice among professional barbers in Ibadan, Nigeria. Afr Health Sci 2009;9(1):19-25.

7. Eroglu C, Zivalioglu M, Esen S, et al. Detection of hepatitis B virus in used razor blades by PCR. Hepatitis Monthly 2010;10:22-25.

8. Karthikeyan K. Tonsuring: Myths and facts. International Journal of Trichology 2009;1(1):33-34. [http://dx.doi.org/10.4103/0974-7753.51927]

9. van Bueren J, Simpson RA, Jacobs P, et al. Survival of human immunodeficiency virus in suspension and dried onto surfaces. J Clin Microbiol 1994;32(2):571-514. 10. Terpstra FG, van den Blink AE, Bos LM, et al. Resistance of surface-dried virus to common disinfection
procedures. J Hosp Infect 2007;66(4):332-338.

Accepted 8 January 2013. 